\title{
Determination of median values of triple screening test hormones for Kayseri region and their cross-regional comparisons
}

\author{
Nahide Ekici Günay \\ Department of Medical Biochemistry, University of Health Sciences, Kayseri City Hospital, Kayseri, Turkey
}

\begin{abstract}
Objective: To determine median values of hormone parameters used in second trimester serum screening test for Kayseri region and to compare the median values with those given in screen report, to assess risk status of cases with new median values, and to compare up-to-date median values for Kayseri region with those from other regions.

Methods: We retrospectively recorded data from 1481 pregnant women (gestational age: 15-20 weeks) who consecutively presented to Kayseri Obstetrics Clinic between February, 2018 and May, 2018 and had triple screen test.

Results: Actual median values for total beta-human chorionic gonadotropin ( $\mathrm{t} \beta-\mathrm{hCG})$, unconjugated estriol $(\mathrm{uE} 3)$ and alpha-fetoprotein (AFP) were found to be lower than those recommended in Prisca software $(\mathrm{p}<0.001)$. When 29 pregnant women reported as risk-free by Prisca software were re-assessed by actual median values, $\mathrm{t} \beta$-hCG MoM cut-off value was found as $>2.5$ with increased risk for Down syndrome. It was found that 12 pregnant women reported as risk-free had $>2.5 \mathrm{MoM}$ for AFP with risk for NTD. Median $t \beta$-hCG values for Kayseri region were found to be lower than those in other regions $(\mathrm{p}<0.01)$.

Conclusion: In accordance with the purpose of the test, it is important that the test should not recommend unnecessary invasive procedures in risk-free pregnancies and should detect true high-risk pregnancies. The identification of population-and laboratory-specific medians will improve test performance.
\end{abstract}

Keywords: Prenatal, diagnosis, risk, alpha-fetoprotein, human chorionic gonadotropin, unconjugated estriol.

\section{Özet: Kayseri bölgesi için üçlü tarama testi hormonlarının ortanca değerlerinin belirlenmesi ve bunların bölgelerarası karşılaştırmaları}

Amaç: Kayseri bölgesi için ikinci trimester serum tarama testinde kullanılan hormon parametrelerinin ortanca değerlerini belirlemek ve ortanca değerleri tarama raporunda bildirilen değerlerle karşılaştırmak, yeni ortanca değerlere sahip olguların risk durumunu değerlendirmek ve Kayseri bölgesinin güncel ortanca değerlerini diğer bölgelerle karşılaştırmak.

Yöntem: Şubat 2018 ve Mayıs 2018 tarihleri arasında art arda Kayseri Doğum Kliniği'ne başvuran ve üçlü tarama testi yaptıran 1481 gebenin (gestasyonel yaş: 15-20 hafta) verilerini retrospektif olarak kaydettik.

Bulgular: Toplam beta-insan koryonik gonadotropini ( $\mathrm{t} \beta-\mathrm{hCG}$ ), serbest östriol (uE3) ve alfa-fetoprotein (AFP) için gerçek ortanca değerlerin, Prisca programında önerilen değerlerden daha düşük olduğu bulundu $(\mathrm{p}<0.001)$. Prisca programı tarafindan risksiz olarak bildirilen 29 gebe gerçek ortanca değerleriyle tekrar değerlendirildiğinde, $\mathrm{t} \beta$-hCG MoM kesme değeri Down sendromu için artan risk ile $>2.5$ olarak bulundu. Risksiz olarak bildirilen 12 gebe, nöral tüp defekti (NTD) için risk içermeyerek AFP için >2.5 MoM değerine sahipti. Kayseri bölgesi için ortanca $t \beta$-hCG değerlerinin, diğer bölgelerden daha düşük olduğu bulundu $(\mathrm{p}<0.01)$.

Sonuç: Test amacımıza uygun olarak, testin risksiz gebeliklerde gereksiz invazif prosedürleri önermemesi ve gerçek yüksek riskli gebelikleri tespit etmesi önemlidir. Popülasyona ve laboratuvara özgü ortanca değerlerin tespiti, test performansını iyileştirecektir.

Anahtar sözcükler: Prenatal, tanı, risk, alfa-fetoprotein, insan koryonik gonadotropini, serbest östriol.

Correspondence: Nahide Ekici Günay, MD. Department of Medical Biochemistry, University of Health Sciences, Kayseri City Hospital, Kayseri, Turkey. e-mail: edihan30@yahoo.com / Received: May 31, 2019; Accepted: September 3, 2019

Please cite this article as: Ekici Günay N. Determination of median values of triple screening test hormones for Kayseri region and their crossregional comparisons. Perinatal Journal 2019;27(2):68-76. doi:10.2399/prn.19.0272004 


\section{Introduction}

The triple screen test is one of the major tests that inform whether infant has congenital anomalies such as Down syndrome (trisomy 21), Edwards syndrome (trisomy 18), Patau syndrome (trisomy 13), Smith-LemliOpitz syndrome (SLOS) and neural tube defect (NTD). ${ }^{[1,2]}$ The test (also known as second trimester screen test) includes serum biochemistry screening performed between 14 and 20 gestational weeks and is based on generating a congenital disease-specific risk ratio by a program using maternal serum total beta-human chorionic gonadotropin ( $\mathrm{t} \beta-\mathrm{hCG}$ ), unconjugated estriol (uE3), alpha-fetoprotein (AFP) values and maternal age as input. ${ }^{[3-5]}$

As with other biochemical parameters, it is needed to measure the parameters accurately in accordance to terms of laboratory carrying out analyses for reliability of risk results reported in triple screen test. The median values used for calculation can be affected by several factors including population, geographic region, ethnicity, age or smoking. ${ }^{[6]}$ The "multiples of median" (MoM) based on regional median values are used for more accurate risk calculation. The MoM is obtained by dividing test result of a certain pregnant women to median value of population, which indicates how far is the result of certain pregnant women from average value of normal population. $^{[7]}$

The aim of present study was to determine median values of hormone parameters used in second trimester serum screening test for Kayseri region and to compare the median values with values given in screen report, to assess risk status of cases with new median values, and to compare up-to-date median values for Kayseri region with those from other regions.

\section{Methods}

The study included women with singleton pregnancy (gestational age: 15-20 weeks) who consecutively presented to Kayseri Obstetrics Clinic between February, 2018 and May, 2018 and underwent triple screen test. The t $\beta$-hCG, uE3 and AFP were measured by IMMULITE $^{\circledR} 2000$ XPi system (Siemens Healthcare Diagnostics, Los Angeles, CA, USA) using chemiluminescence immunoassay technique.

In the assays, the analytic sensitivity is approximately $0.24 \mathrm{ng} / \mathrm{mL}$ for AFP, $0.4 \mathrm{mIU} / \mathrm{mL}$ for $\mathrm{t} \beta-\mathrm{hCG}$, and 0.01 $\mathrm{ng} / \mathrm{mL}$ for $\mathrm{uE} 3$. The within-run coefficient of variation $(\mathrm{CV})$ is around $2.5 \%, 7 \%$, and $8 \%$, respectively.

The gestational age was determined by sonographic measurements of biparietal diameter (BPD) and femur length (FL) based on Hadlock II method. ${ }^{[8]}$ The patients reported as high-risk pregnancy by Prisca software, those with $\mathrm{t} \beta$-hCG level $\geq 2.5 \mathrm{MoM}$, and those with $\mathrm{t} \beta$-hCG, $\mathrm{uE} 3$ and $\mathrm{AFP}<0.5 \mathrm{MoM}$ were excluded. In addition, patients with history of gestational diabetes mellitus, those with newly diagnosed diabetes mellitus, IVF pregnancies, twin pregnancies and smokers were excluded. In all pregnant women included, data regarding diabetes mellitus, smoking status, age, weight, gestational age, BPD measurement and triple screen test parameters including $\mathrm{t} \beta$-hCG, $\mathrm{uE} 3$ and AFP values were entered into PRISCA 5.0 software (Prenatal Risk Estimation Typology Software GmBH, Hamburg, Germany).

The $\mathrm{t} \beta$-hCG, $\mathrm{uE} 3$ and AFP values were recorded according to ultrasonographic gestational ages determined via $\mathrm{BDP}$ and $\mathrm{FL}$ measurements together with demographic data for each pregnant woman and MoM values were determined according to median values of normal population in Prisca software.

Then, actual median value for each parameter was calculated in the pregnant population. A new MoM value was calculated via dividing test value by actual median value. Median values and MoM values for each patient were compared to actual median and MoM values and percent difference was calculated.

The actual median values for Kayseri region were compared to those obtained for İstanbul, Erzurum, Antalya, Van, Bingöl and Eskişehir provinces by IMMULITE 2000 analyzer and same software in similar studies and percent bias values were calculated. ${ }^{[9-14]}$

Statistical analyses were performed by IBM $^{\circledast}$ SPSS $^{\circledast}$ 24.0 (Armonk, NY, USA). Normal distribution was assessed by Shapiro-Wilk test. Descriptive statistics are summarized as median, minimum-maximum and interquartile range (IQR). Median values were calculated for each gestational week and new MoM values were calculated. Wilcoxon signed-rank test was used to compare pregnancy MoM values. Non-parametric sign test was used to compare median values in Prisca software with those obtained for other regions. Interregional percent differences were calculated by 
Windows Excel (Redmond, Washington, USA) software. A p-value $<0.05$ was considered as statistically significant in all analyses.

\section{Results}

Table 1 presents demographic data according to gestational week in 1481 pregnant women included. We calculated new median values for $\mathrm{t} \beta-\mathrm{hCG}, \mathrm{uE} 3$ and $\mathrm{AFP}$ between gestational weeks 15 ( 15 weeks 0 days) and 20 (20 weeks 6 days) and compared these new values with median values in Prisca software (Table 2). In the comparison it was found that all median values for all parameters in Prisca software other than $t \beta-h C G$ on gestational week 20 and AFP on gestational week 15 were significantly higher than regional median values. The highest percent difference was detected in t $\beta$-hCG $(23.3 \%)$ while lowest percent difference was detected in AFP $(11.8 \%)$.

For gestational weeks $15-20$, new MoM values were calculated for each patient and compared with those in Prisca software (Table 3). For $\mathrm{t} \beta-\mathrm{hCG}, \mathrm{MoM}$ values in Prisca software was significantly higher than newly calculated MoM values on gestational weeks 15,18 and 19 $(\mathrm{p}<0.001)$ while they were significantly lower on gestational weeks 16, 17 and $20(\mathrm{p}<0.001)$. For $\mathrm{uE} 3$ and AFP, $\mathrm{MoM}$ values in Prisca software were significantly lower than actual MoM values on all weeks $(\mathrm{p}<0.001)$. When actual MoM values for $\mathrm{t} \beta$-hCG were considered, it was found that MoM value was above cut-off value (2.5) in 3 pregnant women on week 15, 5 pregnant women on week 16,10 pregnant women on week 17,7 pregnant women on week 18 and 4 pregnant women on week 20, and these patients were considered to have increased risk for Down syndrome, all of which were reported as riskfree previously (overall 29 pregnant women). $\mathrm{t} \beta-\mathrm{hCG}$ $\mathrm{MoM}$ values calculated for gestational week 19 did not cause change in risk stratification for Down syndrome. There were 8 pregnant women reported as high-risk for NTD according to Prisca software; however, 12 additional pregnant women had $>2.5 \mathrm{MoM}$ according to actual MoM values for AFP, all which were reported as risk-free previously (overall 20 pregnant women). Two patients were considered as risk-free according to actual MoM values, who were previously reported to be highrisk for SLOS and have $<0.5 \mathrm{MoM}$ value for $\mathrm{uE3}$. Median $\mathrm{t} \beta$-hCG values for Kayseri region were compared to other regions' values (Table 4 and Figs. 1a-c).

\section{Discussion}

Although it is well-known that triple test is a screening tool and does not draw definitive conclusions about fetal problems, reported results play important role in the management of pregnancy for both patient and clinician. There is a strong interest on prenatal triple screen tests given that the diseases associated with chromosomal defect have serious consequences and that only symptomatic benefit can be achieved in such disease currently.

The expression of $\mathrm{t} \beta$-hCG, a triple test analyte, reflects somatic genotypes, and its production is affected by genetic variation. CGB5 is one of six genes that regulate hCG expression. It was shown that CGB5 variation play role in recurrent spontaneous abortions and the gene exhibits region- and population-based variations. ${ }^{[15-17]}$ As a matter of fact, due to the low levels we observed in our region, we suggests that descriptive studies could be carried out on this gene regulating hCG expression.

The AFP, one parameter of triple screen test, is a protein that resembles to fetal-derived albumin in physical and chemical manner. It was shown that AFP plays role in production of osmotic pressure and immunological development of fetus. ${ }^{[18]}$ Maternal serum AFP level is increased in NTD as well as presence of some anomalies and other adverse outcomes including congenital nephrosis, renal agenesis, gastrointestinal atresia, oligohydramnios, threatened abortion, Turner syndrome, triploidy, low birth weight and risk for preeclampsia. ${ }^{[19]}$ Undoubtedly, the diagnostic value of sonographic measurements is higher for NTD when compared to elevated serum APF level. However, elevated AFP MoM values are important in pregnancies without NTD on routine sonographic examination regarding presence of other fetal anomalies and referral to detailed sonographic examination for pregnancy-related complications as well as monitoring for potential complications during delivery ${ }^{[20]}$ According to our results of the region, calculated AFP median values were evaluated as babies with overlooked probable problems. In other words, because of the standard median data used by the software program, MoM values could not be calculated accurately and true high fetal risks could not be reported to the obstetrician. In the triple screen test using maternal $t \beta$ hCG, $\mathrm{uE} 3$ and AFP values, the detection rates are about 
Table 1. Demographic data of pregnants.

\begin{tabular}{|c|c|c|c|c|}
\hline & & Median \pm SE & IQR & Min-max \\
\hline \multirow[t]{8}{*}{ 15th week $(n=230)$} & Age (year) & $25.6 \pm 0.42$ & 9.2 & $18.1-42.1$ \\
\hline & Weight (kg) & $65.3 \pm 0.95$ & 8.6 & 45-103 \\
\hline & $\beta$-hCG (mIU/mL) & $23,214 \pm 2156$ & 14,820 & $5584-98,249$ \\
\hline & $\beta$-hCG (MoM) & $0.87 \pm 0.09$ & 0.64 & $0.24-4.23$ \\
\hline & uEз $(\mathrm{ng} / \mathrm{mL})$ & $0.45 \pm 0.03$ & 0.292 & $0.127-1.07$ \\
\hline & uЕз (МоM) & $1.09 \pm 0.07$ & 0.65 & $0.44-2.23$ \\
\hline & AFP (IU/ml) & $25.4 \pm 3.8$ & 15.1 & $10-225$ \\
\hline & AFP (MoM) & $0.96 \pm 0.02$ & 0.53 & $0.47-5.25$ \\
\hline \multirow[t]{8}{*}{ 16th week $(n=277)$} & Age (year) & $25.3 \pm 0.58$ & 8.2 & $15.2-48$ \\
\hline & Weight (kg) & $65.9 \pm 1.52$ & 18 & 44-108 \\
\hline & $\beta$-hCG (mlU/mL) & $21,647 \pm 1388$ & 11,709 & $4876-56,571$ \\
\hline & $\beta$-hCG (MoM) & $1.04 \pm 0.05$ & 0.4 & $0.2-2.08$ \\
\hline & uEз $(\mathrm{ng} / \mathrm{mL})$ & $0.55 \pm 0.03$ & 0.27 & $0.16-1.46$ \\
\hline & uEз (MoM) & $0.81 \pm 0.06$ & 0.45 & $0.28-1.81$ \\
\hline & AFP (IU/ml) & $26.05 \pm 2.4$ & 15.4 & $0.8-121$ \\
\hline & AFP (MoM) & $0.93 \pm 0.06$ & 0.4 & $0.20-2.08$ \\
\hline \multirow[t]{8}{*}{ 17th week $(n=284)$} & Age (year)) & $25.56 \pm 0.68$ & 9.5 & $17.1-43.5$ \\
\hline & Weight (kg) & $66.1 \pm 0.8$ & 11 & 46-108 \\
\hline & $\beta$-hCG (mlU/mL) & $15,785 \pm 1129$ & 11,611 & $1774-95,408$ \\
\hline & $\beta$-hCG (MoM) & $1.20 \pm 0.08$ & 0.59 & $0.20-3.44$ \\
\hline & uE3 $(\mathrm{ng} / \mathrm{mL})$ & $0.72 \pm 0.26$ & 0.34 & $0.19-1.71$ \\
\hline & uE3 (MoM) & $0.89 \pm 0.05$ & 0.35 & $0.23-1.94$ \\
\hline & AFP (IU/ml) & $30.20 \pm 2.29$ & 16.8 & $11.9-103$ \\
\hline & AFP (MoM) & $0.99 \pm 0.06$ & 0.59 & $0.20-3.44$ \\
\hline \multirow[t]{8}{*}{ 18th week $(n=253)$} & Age (year) & $24.9 \pm 0.92$ & 12 & $16.5-41.8$ \\
\hline & Weight (kg) & $67.1 \pm 0.6$ & 9.6 & 45-113 \\
\hline & $\beta$-hCG (mlU/mL) & $14,295 \pm 1156$ & 10631 & $1509-86,067$ \\
\hline & $\beta$-hCG (MoM) & $1.01 \pm 0.06$ & 0.47 & $0.16-2.09$ \\
\hline & uE3 $(\mathrm{ng} / \mathrm{mL})$ & $0.91 \pm 0.40$ & 0.41 & $0.33-3.94$ \\
\hline & uEз (MoM) & $1.00 \pm 0.04$ & 0.36 & $0.29-1.65$ \\
\hline & AFP (IU/ml) & $35.35 \pm 2.56$ & 17.3 & $12.9-110$ \\
\hline & AFP (MoM) & $0.94 \pm 0.07$ & 0.37 & $0.33-2.96$ \\
\hline \multirow[t]{8}{*}{ 19th week $(n=288)$} & Age (year) & $26.8 \pm 0.9$ & 9.6 & $17.2-41.8$ \\
\hline & Weight (kg) & $68 \pm 0.9$ & 11 & $48-110$ \\
\hline & $\beta$-hCG (mlU/mL) & $15,190 \pm 1084$ & 9557 & $4233-38,505$ \\
\hline & $\beta$-hCG (MoM) & $1.0 \pm 0.05$ & 0.62 & $0.31-1.63$ \\
\hline & uE3 $(\mathrm{ng} / \mathrm{mL})$ & $1.11 \pm 0.03$ & 0.53 & $0.144-3.45$ \\
\hline & uEз (MoM) & $0.96 \pm 0.04$ & 1.44 & $0.42-1.86$ \\
\hline & AFP (IU/ml) & $40 \pm 2.49$ & 21.4 & $9.8-116$ \\
\hline & AFP (MoM) & $0.96 \pm 0.05$ & 0.45 & $0.29-1.69$ \\
\hline \multirow[t]{8}{*}{ 20th week $(n=149)$} & Age (year) & $25.4 \pm 0.7$ & 8.8 & $17.8-40.8$ \\
\hline & Weight (kg) & $70.1 \pm 1.2$ & 8.5 & 46-108 \\
\hline & $\beta$-hCG (mlU/mL) & $14,501 \pm 1415$ & 14493 & $3984-38,442$ \\
\hline & $\beta$-hCG (MoM) & $1.03 \pm 0.08$ & 0.77 & $0.26-2.47$ \\
\hline & uE3 $(\mathrm{ng} / \mathrm{mL})$ & $1.31 \pm 0.04$ & 0.793 & $0.618-2.59$ \\
\hline & uEз (MoM) & $0.99 \pm 0.04$ & 0.48 & $0.42-1.45$ \\
\hline & AFP (IU/ml) & $45.30 \pm 4.20$ & 22.6 & $21.6-187$ \\
\hline & AFP (MoM) & $1.01 \pm 0.07$ & 0.36 & $0.46-3.36$ \\
\hline
\end{tabular}

ß-hCG: human chorionic gonadotrophin; AFP: alpha-fetoprotein; IQR: interquartile range; SE: standard error; UE3: unconjugated estriol. 
Table 2. Comparison of the triple test parameters in the newly calculated median values and Prisca program.

\begin{tabular}{|c|c|c|c|c|c|}
\hline \multirow[b]{2}{*}{ Gestational week } & \multicolumn{5}{|c|}{ Total $\beta$-hCG (mIU/mL) } \\
\hline & n & Current median & Prisca median & $\mathbf{p}$ & bias \% \\
\hline 15 & 230 & 23,214 & 34,820 & $<0.001$ & 33.33 \\
\hline 16 & 277 & 21,647 & 26,783 & $<0.001$ & 19.18 \\
\hline 17 & 284 & 15,785 & 22,865 & $<0.001$ & 30.96 \\
\hline 18 & 253 & 14,295 & 19,931 & $<0.001$ & 28.28 \\
\hline 19 & 288 & 15,190 & 18,057 & $<0.001$ & 15.88 \\
\hline 20 & 149 & 14,501 & 16,528 & 0.846 & 12.26 \\
\hline \multirow[b]{2}{*}{ Gestational week } & \multicolumn{5}{|c|}{ Unconjugated estriol (ng/mL) } \\
\hline & $\mathbf{n}$ & Current median & Prisca median & $\mathbf{p}$ & bias $\%$ \\
\hline 15 & 230 & 0.45 & 0.53 & 0.023 & 15.09 \\
\hline 16 & 277 & 0.55 & 0.74 & $<0.001$ & 25.68 \\
\hline 17 & 284 & 0.72 & 0.87 & $<0.001$ & 17.24 \\
\hline 18 & 253 & 0.91 & 1.17 & $<0.001$ & 22.22 \\
\hline 19 & 288 & 1.11 & 1.38 & $<0.001$ & 19.57 \\
\hline 20 & 149 & 1.31 & 1.87 & $<0.001$ & 29.95 \\
\hline \multirow[b]{2}{*}{ Gestational week } & \multicolumn{5}{|c|}{ Alpha-fetoprotein (IU/ml) } \\
\hline & $\mathbf{n}$ & Current median & Prisca median & $\mathbf{p}$ & bias $\%$ \\
\hline 15 & 230 & 25.40 & 26.60 & 0.911 & 4.51 \\
\hline 16 & 277 & 26.05 & 30.30 & 0.004 & 14.03 \\
\hline 17 & 284 & 30.20 & 34.45 & 0.004 & 12.34 \\
\hline 18 & 253 & 35.35 & 40.60 & 0.016 & 12.93 \\
\hline 19 & 288 & 40.00 & 46.55 & $<0.001$ & 14.07 \\
\hline 20 & 149 & 45.30 & 52.10 & 0.033 & 13.05 \\
\hline
\end{tabular}

Sign test for medians. $\boldsymbol{\beta}$-hCG: $\beta$-human chorionic gonadotrophin.

$60-65 \%$ for trisomy 21 and 18 , and $75-80 \%$ for neural tube defects. ${ }^{[2]]}$ Again, it measures AFP, $\mathrm{uE3}$ and $\mathrm{t} \beta-$ hCG with a sensitivity of $60 \%$ and false-positive rate of $5 \% .{ }^{[22]}$ Although the triple screening test result is not a diagnostic, it is important in terms of referral to detailed ultrasonographic test request and decision of amniocentesis. By the reporting laboratory, failure to use analytical median values obtained from the regional pregnant community is an important factor that may affect the clinician's performance in patient follow-up and management (such as the request for advanced ultrasonographic examination or decision of amniocentesis).

As with other biochemical parameters, factors such as ethnicity, age and smoking used in risk calculation in triple screen test can alter median values in the center carrying out studies. In this context, concordance between regional median values and those used in the software is an important requirement which influences on performance regarding accurate risk identification and decision-making process in the pregnancy.

Triple test result aids preparation of parent for delivery. If all test results are normal, parents are assured that likelihood of infant with genetic disorder is low. However, early recognition of high-risk pregnancies will add advantage to parents for better management of delivery and to attending clinician for management of potential complications. 
Table 3. Comparison of triple test parameters with MoM values calculated according to currently and Prisca program medians.

\begin{tabular}{|c|c|c|c|c|c|}
\hline \multirow[b]{2}{*}{ Gestation week } & \multicolumn{5}{|c|}{ Total $\beta$-hCG (mlU/mL) } \\
\hline & $\mathbf{n}$ & Current MoM (mean) & Prisca MoM (mean) & $\mathbf{p}$ & bias $\%$ \\
\hline 15 & 230 & 1.09 & 0.97 & $<0.001$ & -12.4 \\
\hline 16 & 277 & 1.11 & 0.93 & $<0.001$ & -19.4 \\
\hline 17 & 284 & 1.19 & 1.12 & $<0.001$ & -6.2 \\
\hline 18 & 253 & 1.14 & 0.81 & $<0.001$ & -40.7 \\
\hline 19 & 288 & 1.02 & 0.91 & $<0.001$ & -12.1 \\
\hline 20 & 149 & 1.17 & 1.07 & $<0.001$ & -9.3 \\
\hline \multirow[b]{2}{*}{ Gestation week } & \multicolumn{5}{|c|}{ Unconjugated estriol (ng/mL) } \\
\hline & $\mathbf{n}$ & Current MoM (mean) & Prisca MoM (mean) & $\mathbf{p}$ & bias $\%$ \\
\hline 15 & 230 & 1.12 & 0.98 & $<0.001$ & -14.3 \\
\hline 16 & 277 & 1.04 & 0.83 & $<0.001$ & -25.3 \\
\hline 17 & 284 & 1.03 & 0.80 & $<0.001$ & -28.8 \\
\hline 18 & 253 & 1.06 & 0.84 & $<0.001$ & -26.2 \\
\hline 19 & 288 & 1.09 & 0.86 & $<0.001$ & -26.7 \\
\hline 20 & 149 & 1.06 & 0.85 & $<0.001$ & -14.3 \\
\hline \multirow[b]{2}{*}{ Gestation week } & \multicolumn{5}{|c|}{ Alpha-fetoprotein (IU/ml) } \\
\hline & n & Current MoM (mean) & Prisca MoM (mean) & $\mathbf{p}$ & bias $\%$ \\
\hline 15 & 230 & 1.20 & 1.04 & $<0.001$ & -15.4 \\
\hline 16 & 277 & 1.11 & 0.87 & $<0.001$ & -27.6 \\
\hline 17 & 284 & 1.08 & 0.89 & $<0.001$ & -21.3 \\
\hline 18 & 253 & 1.09 & 0.94 & $<0.001$ & -16.0 \\
\hline 19 & 288 & 1.07 & 0.88 & $<0.001$ & -21.6 \\
\hline 20 & 149 & 1.11 & 0.93 & $<0.001$ & -19.4 \\
\hline
\end{tabular}

Wilcoxon signed-rank test. $\boldsymbol{\beta}$-hCG: human $\beta$ chorionic gonadotrophin.

Among other reasons, strong interest to triple screen test in prenatal diagnosis is due to higher costs and limited access to laboratory technologies despite being noninvasive and high diagnostic values. ${ }^{[23]}$

When median values obtained for Kayseri region were compared to those obtained for İstanbul, Erzurum, Antalya, Van, Bingöl and Eskişehir by similar studies, it was found that there was no significant difference in median $\mathrm{t} \beta$-hCG values on weeks 19 and 20 while median $\mathrm{t} \beta$-hCG values on week 17 and 28 were found to be significantly lower than those obtained for all regions $(\mathrm{p}<0.001)$.

Actual median uE3 values on all weeks were found to be significantly lower than those for Erzurum province $(\mathrm{p}<0.001)$. There was no significant difference in actual median uE3 values on all weeks other than week 18 between Van and Kayseri region.

Regarding AFP, there was no significant difference in actual median values on all weeks between Kayseri and İstanbul, Erzurum and Van provinces. Interregional bias was found to be significantly higher on the weeks 16-18 (considered as optimal timing for triple screen test) when compared to remaining weeks.

Strong immigration dynamics is remarkable in Kayseri region. It is essential to perform similar studies and to keep median value pools up-to-date in geographic regions which have high potential for changes 
Table 4. Comparison of median values of Kayseri region with median values of some regions.

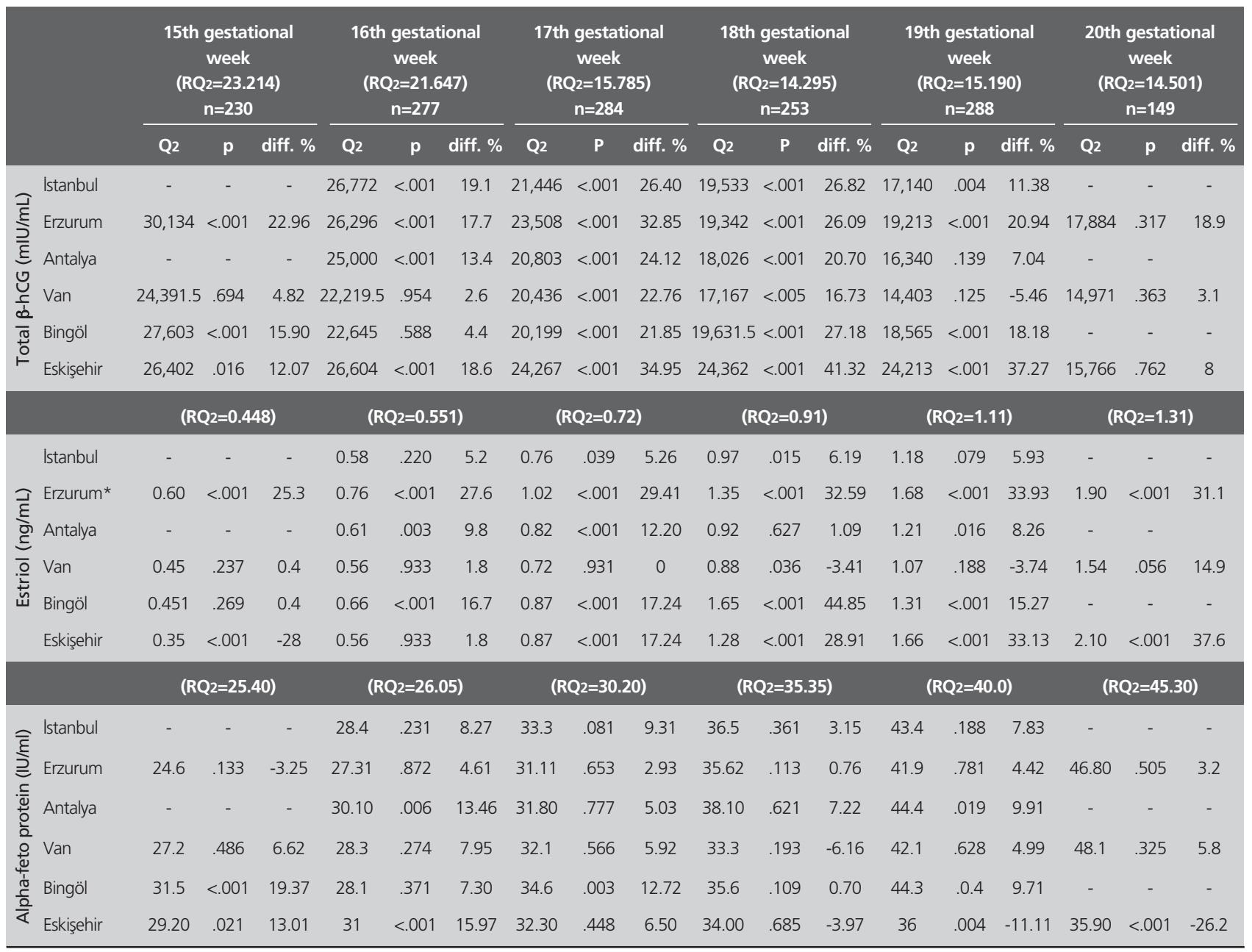

Sign test for medians, diff.: difference; Q2: median; RQ2: regional median of Kayseri. Estriol median values for Erzurum region were divided into 3.47 and converted from $\mathrm{nmol} / \mathrm{L}$ to $\mathrm{ng} / \mathrm{mL}$. -: no data.

in population characteristics (age, weight, and ethnicity) over time and high pregnancy rate. In fact, $16 \%$ of consecutive subjects included to our study were moved to our region within prior years, reflecting monthly average in 2018 in the study center.

In our study, lower median $\mathrm{t} \beta$-hCG values when compared to those in Prisca software and those obtained for other geographic regions may promote genetic sequence analyses that regulate the hormone known to be affected by genetic variation.

Due to retrospective design, the study is limited by lack of detailed sonographic reports and pregnancy outcomes in patients who were reported to be risk-free previously but found to be at risk according to actual median values.

\section{Conclusion}

In accordance with the purpose of the triple screening test, it is important that the test should not produce recommendation of unnecessary invasive procedures in risk-free pregnancies and should detect true risky pregnancies. The test performance will be improved by determination of population-specific regional median values. The knowledge of regional variation in different 
a

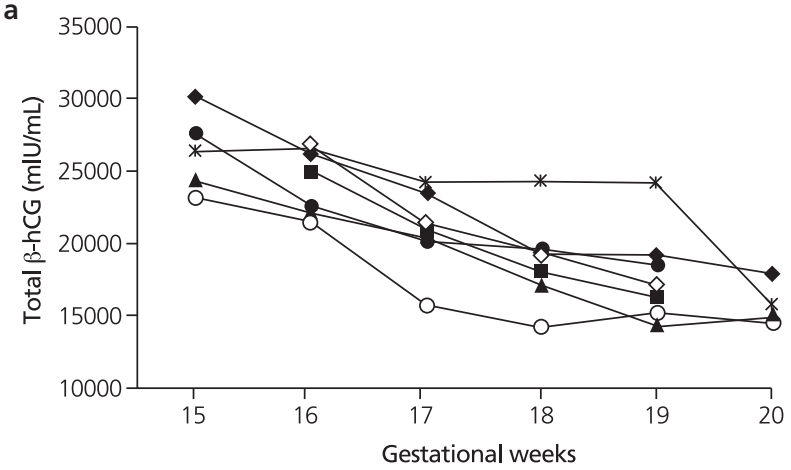

b

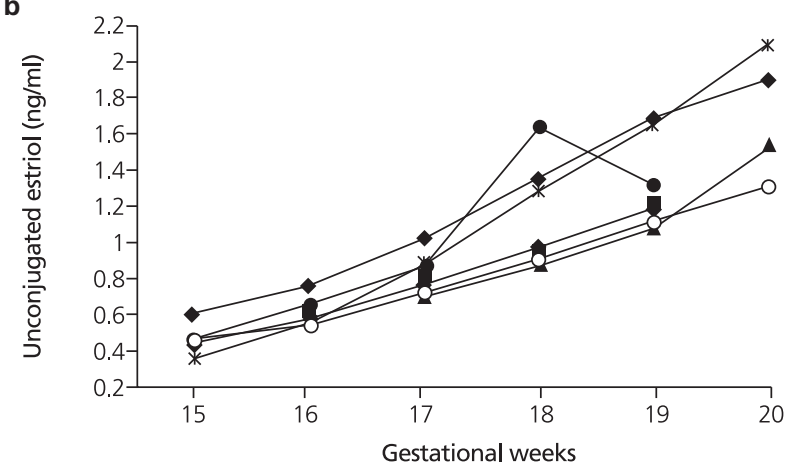

c

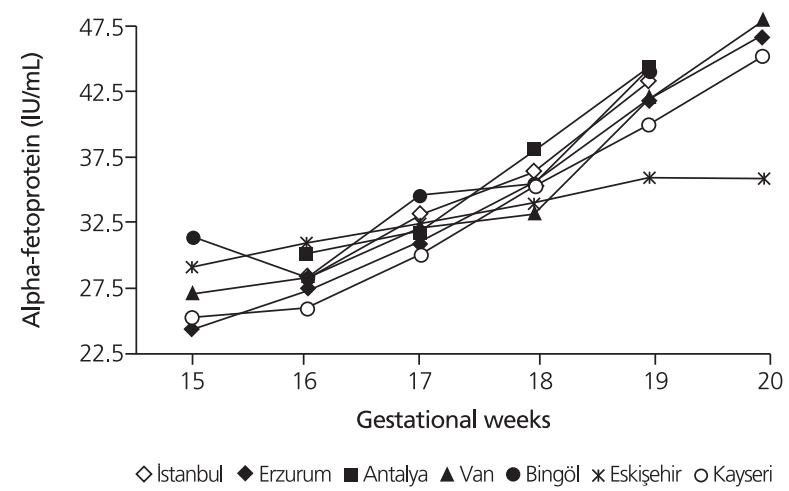

Fig. 1. Median values by regions for (a) total $\beta$-human chorionic gonadotrophin ( $\mathrm{t} \beta-h C \mathrm{C})$, (b) for unconjugated estriol (uE3) and (c) for alpha-fetoprotein (AFP).

gestational weeks will be helpful to report and interpret results. In fact, MoM values are used for standardization of results. However, MoM performance will be affected unless they are actual or region-specific. It is an analytical requirement that the central immunoassay laboratory determine the prenatal screening tests' hormone medians for the population it serves. Identification of regional current median values of hormones used in pre- natal screening tests will contribute to map median values in our country, to ensure standardization among different laboratories and to create software used in risk estimation.

Conflicts of Interest: No conflicts declared.

\section{References}

1. Palomaki GE, Haddow JE, Knight GJ, Wald NJ, Kennard A, Canick JA, et al. Risk-based prenatal screening for trisomy 18 using alpha-fetoprotein, unconjugated oestriol and human chorionic gonadotropin. Prenat Diagn 1995;15:71323.

2. Craig WY, Haddow JE, Palomaki GE, Roberson M. Major fetal abnormalities associated with positive screening tests for Smith-Lemli-Opitz syndrome (SLOS). Prenat Diagn 2007;27:409-14.

3. Reynolds $\mathrm{T}$. The triple test as a screening technique for Down syndrome: reliability and relevance. Int J Womens Health 2010;2:83-8.

4. Onrat ST, Seyman H, Konuk M. Incidence of neural tube defects in Afyonkarahisar, Western Turkey. Genet Mol Res 2009;8:154-61.

5. Acikbas I, Tomatir AG, Akdag B, Koksal A. Retrospective analysis of live birth prevalence of children with Down syndrome in Denizli, Turkey. Genet Mol Res 2012;11:4640-5.

6. Peter $\mathrm{AB}$, Jonathan $\mathrm{M}$, Colins C. Medians for second trimester maternal serum alpha-fetoprotein, human chorionic gonadotropin and unconjugated estriol; differences between races or ethnic groups. Clin Chem 1997;43:333-7.

7. Burtis CA, Ashwood ER, Bruns DE. Tietz textbook of clinical chemistry and molecular diagnostics. Philadelphia, PA: Elsevier Saunders; 2006. p. 2168.

8. Hadlock FP, Deter RL, Harrist RB, Park SK. Estimating fetal age: computer-assisted analysis of multiple fetal growth parameters. Radiology 1984;152:497-501.

9. Sucu V, Yildirmak S, Vardar M, Mihmanlı V. Determination of the median levels of double and triple screening test parameters in our hospital. [Article in Turkish] Abant Medical Journal 2018;7:35-40.

10. Yilmaz A. Determination of the median values of triple test screening parameters in Erzurum region. [Article in Turkish] Türk Klinik Biyokimya Dergisi 2009;7:37-41.

11. Akalın N, Arıkan S. Determination of the median levels of triple test screening parameters in our region. Perinatal Journal 2007;15:12-9.

12. Alp HH, Huyut Z, Çokluk E, Şekeroğlu MR. Median values of double and triple prenatal screening tests: a van scale restrospective study. [Article in Turkish] Türk Klinik Biyokimya Dergisi 2018;16:17-24.

13. Duran İ. Determination of the median values of triple test screening parameters in Bingol region. [Article in Turkish] Türk Klinik Biyokimya Dergisi 2017;15:37-44.

14. Şanlı DB, Kartkaya K. Determination of the median levels of triple test screening parameters in Eskişehir region. [Article in Turkish] Turkish Journal of Biochemistry 2011;36;50-4. 
15. Policastro PF, Daniels-McQueen S, Carle G, Boime I. A map of the hCG beta-LH beta gene cluster. J Biol Chem 1986;261:5907-16.

16. Rull K, Christiansen OB, Nagirnaja L, Steffensen R, Margus T, Laan M. A modest but significant effect of CGB5 gene promoter polymorphisms in modulating the risk of recurrent miscarriage. Fertil Steril 2013;99:1930-6.

17. Rull K, Nagirnaja L, Ulander V-M, Kelgo P, Margus T, Kaare M, et al. Chorionic gonadotropin beta-gene variants are associated with recurrent miscarriage in two European populations. J Clin Endocrinol Metab 2008;93:4697-706.

18. Nicholas NS. Human fetal allograft survival. In: Studd J, editor. Progress in Obstetrics and Gynecology. Edinburgh: Churchill Livingstone; 1983. p. 97:12.

19. Spaggiari E, Ruas M, Dreux S, Valat AS, Czerkiewicz I, Guimiot F, et al. Management strategy in pregnancies with elevated second-trimester maternal serum alpha-fetoprotein based on a second assay. Am J Obstet Gynecol 2013;208: 303.e1-7.

20. Ghi T, Pilu G, Falco P, Segata M, Carletti A, Cocchi G, et al. Prenatal diagnosis of open and closed spina bifida. Ultrasound Obstet Gynecol 2006;28:899-903.

21. Moghadam MN, Davoodi M, Behzadmehr R. Prenatal diagnosis. Journal of Medical Practice and Review 2018;2:11922.

22. Lao MR, Calhoun BC, Bracero LA, Wang Y, Seybold DJ, Broce $M$, et al. The ability of the quadruple test to predict adverse perinatal outcomes in a high-risk obstetric population. J Med Screen 2009;16:55-9.

23. García-Pérez L, Linertová R, Álvarez-de-la-Rosa M, Bayón JC, Imaz-Iglesia I, Ferrer-Rodríguez J, et al. Cost-effectiveness of cell-free DNA in maternal blood testing for prenatal detection of trisomy 21, 18 and 13: a systematic review. Eur J Health Econ 2018;19:979-91.

Bu makalenin kullanım izni Creative Commons Attribution-NoCommercial-NoDerivs 3.0 Unported (CC BY-NC-ND3.0) lisansı aracılı̆̆ılyla bedelsiz sunulmaktadir. / This work is licensed under the Creative Commons Attribution-NonCommercial-NoDerivs 3.0 Unported (CC BY-NC-ND3.0) License. To view a copy of this license, visit http://creativecommons.org/licenses/by-nc-nd/3.0/ or send a letter to Creative Commons, PO Box 1866 , Mountain View, CA 94042, USA. 